\title{
JUURNAL of NUTRITIIIN CDLLEeE
}

Volume 8, Nomor 4, Tahun 2019, Halaman 246-253

Online di : http://ejournal3.undip.ac.id/index.php/jnc/

Submitted : 1 September 2019

Accepted : 2 November 2019

\section{HUBUNGAN ANTARA ASUPAN PROTEIN DAN KADAR PROTEIN AIR SUSU IBU}

\author{
Lien Meilya Muriasti Prastiyani, Nuryanto* \\ Departemen Ilmu Gizi, Fakultas Kedokteran, Universitas Diponegoro \\ J1. Prof. Sudarto SH, Tembalang, Semarang, Jawa Tengah 50275, Indonesia \\ *Penulis Penanggungjawab. E-mail: nyt_gizi@yahoo.com
}

\begin{abstract}
Background: Breast milk is the best food for babies 0-6 months because it contains all the nutrients needed by babies and contains antibodies to protect babies from disease. One of the nutrients in breast milk is influenced by nutrient intake. Protein is one of the nutrients that plays a role in the growth, formation of important tissues and organs and the defense of the baby's body. The aim of this study was to determine the association of protein intake with protein contents of breast milk.

Method: These research was observational with a cross sectional study design. Subject in this study were 33 breastfeeding mothers in Sub-district Candisari and Sub-district Tembalang were selected by random sampling method. Protein intake was obtained through recall of $3 \times 24$ hours through interviews with the food recall method with different days. Protein contents of breast milk were analyzed by Kjeldahl method. The association between protein intake with protein contents of breast milk was analyzed by Rank Spearman correlation.

Result: Average protein intake was 58.06 \pm 10.51 gram and average level of protein intake was $49.74 \pm 9.29 \%$. These results showed that there was a significant correlation between protein intake with protein contents of breast milk ( $p=$ 0.029).
\end{abstract}

Conclusion: There was a significant correlation between protein intake with protein contents of breast milk.

Keyword: Protein intake, protein contents of breast milk

\section{ABSTRAK}

Latar Belakang: ASI merupakan makanan terbaik bayi 0-6 bulan karena mengandung semua unsur zat gizi yang dibutuhkan bayi serta mengandung antibodi untuk melindungi bayi dari penyakit. Kandungan zat gizi ASI salah satunya dipengaruhi oleh asupan zat gizi. Protein merupakan salah satu zat gizi yang berperan dalam pertumbuhan, pembentukan jaringan dan organ penting dan pertahanan tubuh bayi.Tujuan penelitian ini adalah untuk mengetahui hubungan antara asupan protein dengan kadar protein air susu ibu (ASI).

Metode: Jenis penelitian ini adalah observasional dengan desain studi cross sectional. Jumlah sampel sebanyak 33 orang ibu menyusui bayi 0-6 bulan di wilayah Kecamatan Candisari dan Kecamatan Tembalang yang dipilih secara acak. Asupan protein diperoleh melalui recall 3x24 jam melalui wawancara dengan metode food recall dengan hari yang berbeda. Kadar protein ASI dianalisis dengan metode Kjeldahl. Hubungan antara asupan protein dengan kadar protein ASI diuji menggunakan uji korelasi Rank Spearman.

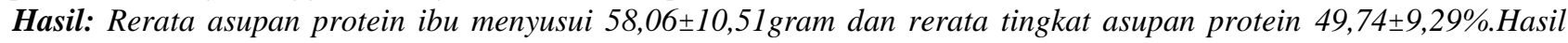
penelitian menunjukkan adanya hubungan signifikan antara asupan protein dengan kadar protein ASI dengan nilai $p=$ $0,029(p<0,05)$.

Simpulan: Terdapat hubungan signifikan antara asupan protein dengan kadar protein ASI.

Kata kunci : Asupan protein, kadar protein ASI, air susu ibu (ASI)

\section{PENDAHULUAN}

Air Susu Ibu (ASI) adalah cairan air susu hasil sekresi dari payudara setelah ibu melahirkan. ASI merupakan sumber gizi utama bayi terutama pada usia 0-6 bulan dimana bayi belum dapat mencerna makanan padat. ASI merupakan sumber makanan terbaik bagi bayi karena mengandung semua unsur zat gizi yang dibutuhkan bayi dengan temperatur yang sesuai dengan bayi, susunya segar dan bebas dari kontaminasi bakteri sehingga mengurangi risiko gangguan gastrointestinal. Selain itu, ASI juga mengandung zat kekebalan yang akan melindungi bayi dari berbagai penyakit infeksi, bakteri, virus, parasit, dan jamur. ${ }^{1,2,3}$ Hal-hal tersebut menjadikan ASI sebagai satu-satunya makanan terbaik dan paling cocok untuk bayi. ${ }^{4,5}$

Air Susu Ibu Eksklusif (ASI Eksklusif) adalah ASI yang diberikan kepada bayi sejak dilahirkan hingga 6 bulan, tanpa menambahkan dan atau mengganti dengan makanan atau minuman lain kecuali vitamin, oralit dan obat. ${ }^{6}$ Kualitas dan jumlah makanan yang dikonsumsi ibu sangat berpengaruh pada jumlah ASI yang dihasilkan. ASI mengandung zat gizi, hormon, unsur kekebalan 
pertumbuhan, anti alergi, serta anti inflamasi bagi tubuh bayi usia 0-6 bulan. Bayi yang mendapatkan susu formula mungkin lebih gemuk dari pada bayi yang mendapatkan ASI, tetapi belum tentu lebih sehat. ${ }^{7}$

Air susu ibu (ASI) juga dipengaruhi oleh asupan nutrisi dan kondisi psikologis ibu. Ibu menyusui memerlukan tambahan energi lebih banyak sekitar $700 \mathrm{kkal} / \mathrm{hari}$ untuk mencukupi seluruh atau minimal $80 \%$ nutrisi yang diperlukan oleh bayi 0-6 bulan. Bayi 6-12 bulan sudah mulai diberikan makanan pendamping ASI sehingga tambahan kebutuhan energi ibu lebih sedikit yaitu $500 \mathrm{kkal} / \mathrm{hari}$. Ibu menyusui membutuhkan tambahan nutrisi khususnya nutrisi kaya protein (ikan, telur), kalsium (susu), dan vitamin (sayur, buah) serta banyak konsumsi air putih. ${ }^{8}$

Produksi ASI dipengaruhi oleh frekuensi pengisapan puting susu ibu oleh bayi, sedangkan volume ASI dipengaruhi oleh hidrasi dari ibu. Produksi ASI dipengaruhi oleh hormon oksitosin, hormon prolaktin, refleks prolaktin dan let-downrefleks. Pada saat bayi menghisap puting maka akan terjadi reflek prolaktin yang akan merangsang hormon prolaktin untuk memproduksi ASI dan letdown refleks yang akan merangsang pengaliran ASI. ${ }^{9}$

Protein merupakan salah satu zat gizi yang berperan dalam pertumbuhan, pembentukan jaringan dan organ penting dan pertahanan tubuh. Pada awal pertumbuhan manusia memperoleh protein dari ASI(Air Susu Ibu). ${ }^{10}$ Protein pada ASI mengandung asam amino yang memiliki peran penting untuk pertumbuhan bayi, oleh sebab itu kebutuhan protein pada bayi harus terpenuhi. ${ }^{11}$ Kekurangan gizi pada masa bayi merupakan faktor terbesar terjadinya kelambatan pertumbuhan dan biasanya disebabkan oleh defisiensi energi dan protein. ${ }^{12}$ Kandungan protein pada ASI lebih mudah diserap oleh tubuh dibandingkan dengan protein yang dihasilkan oleh susu sapi. Hal ini dikarenakan kandungan protein (whey dan kasein ) ASI dan susu sapi memiliki daya serap yang berbeda di dalam tubuh. ${ }^{13}$

Penyebab produksi dan kandungan ASI tidak optimal salah satunya adalah asupan gizi yang kurang baik, menu makanan yang tidak seimbang dan konsumsi makanan yang tidak teratur. Menurut AKG 2013 ibu menyusui 6 bulan pertama membutuhkan asupan protein tambahan sebesar 20 gram per hari. Asupan protein ibu menyusui yang kurang dapat menyebabkan konsentrasi kasein dalam ASI tidak memadai. Kasein berperan dalam penyerapan kalsium dan fosfat di dalam usus bayi dan memiliki fungsi imunomodulator. ${ }^{14}$
Persentase rata-rata cakupan pemberian ASI Eksklusif 6 bulan di Indonesia pada tahun 2017 sebesar $46,47 \%$ angka cakupan pemberian ASI Eksklusif ini menurun bila dibandingkan pada tahun 2016 sebesar 54,0\%. Angka cakupan pemberian ASI Eksklusif di Jawa Tengah juga terjadi penurunan pada tahun 2017 sebesar 55,47\% dibandingkan dengan tahun 2016 sebesar 59,9\%, sedangkan prevalensi cakupan ASI Eksklusif di Kota Semarang pada Tahun 2017 sebesar 67,33 \% cakupan ini mengalami peningkatan dibandingkan dengan tahun 2016 sebesar 67,16\%.15,16 Berdasarkan uraian tersebut, peneliti tertarik untuk meneliti lebih lanjut terkait hubungan asupan protein ibu menyusui dengan kadar protein pada air susu ibu di wilayah Kecamatan Candisari dan Kecamatan Tembalang.

\section{METODE}

Penelitian ini merupakan penelitian observasional dengan desain studi cross sectional. Penelitian dilaksanakan pada bulan Juni hingga Juli 2019 di wilayah Kecamatan candisari dan Kecamatan Tembalang, Semarang. Subjek pada penelitian ini adalah ibu menyusui bayi 0-6 bulan. Jumlah sampel penelitian ini sebanyak 33 subjek yang diperoleh dari rumus perhitungan besar sampel berdasarkan koefisien korelasi penelitian sebelumnya dan dipilih secara acak. Kriteria inklusi pada penelitian ini yaitu ibu menyusui bayi usia 0-6 bulan yang bersedia menjadi sampel dengan mengisi Informed Concern (IC), tercatat sebagai warga di daerah Kecamatan Candisari dan Kecamatan Tembalang, subjek berada di tempat saat penelitian dilakukan, masih mempunyai suami dan tinggal bersama. Kriteria eksklusi pada penelitian ini adalah subjek sakit, mengundurkan diri, pindah atau meninggal.

Subjek yang terpilih dan bersedia menjadi subjek penelitian diberikan IC sebagai bentuk persetujuan. Subjek diberikan kuesioner penelitian untuk mengetahui karakteristik subjek. Data yang dikumpulkan meliputi nama ibu, usia ibu, usia menyusui, pengukuran tinggi badan menggunakan microtoice dengan ketinggian maksimal $200 \mathrm{~cm}$, dan tingkat ketelitian $0,1 \mathrm{~cm}$, pengukuran berat badan menggunakan timbangan digital injak dengan ketelitian $0,1 \mathrm{~kg}$, pekerjaan ibu dan pendidikan terakhir ibu, wawancara menggunakan kuesioner terstruktur. Data biokimia meliputi ASI yang diambil dalam kurun waktu 1x24 jam. ASI didapatkan dari pemerahan pagi-malam hari untuk mencukupi $50 \mathrm{ml}$ sebagai sampel penelitian, kemudian dimasukkan ke dalam kantong ASI yang sudah disediakan oleh peneliti. Pemerahan ini menggunakan alat pemerah listrik yang sudah disediakan oleh peneliti. Selain itu data yang 
dikumpulkan berupa ASI subjek yang sudah diperah dan dimasukkan ke dalam kantong ASI yang sudah disiapkan untuk dianalisis kadar proteinnya.Ibu diberikan informasi untuk menyimpan ASInya yang telah diperah pada malam hari dan harus disimpan di lemari pendingin bila punya. Bila tidak mempunyai lemari pendingin diambil langsung oleh peneliti untuk disimpan. ASI yang didapat dari subjek dibawa menggunakan Cooler Box. Sebelum melalukan pemerahan sebaiknya dilakukan pemijatan selama 2-3 menit pada payudara. Analisis kadar protein ASI diuji dengan metode Kjeldahl di laboratorium PT Angler Biochemlab Surabaya.

Data asupan makanan ibu diperoleh dari wawancara food recall asupan 3x24 jam pada subjek untuk melihat rerata asupan zat gizi subjek. Data recall asupan yang diperoleh kemudian dianalisis menggunakan software nutrisurvey 2007 untuk menganalisis asupan zat gizi subjek. Tingkat kecukupan asupan energy, karbohidrat, lemak, dan protein ditentukan dengan rumus Harris Beneditct.

Penelitian kadar protein ASI dan persentase asupan protein diuji normalitas dengan uji ShapiroWilk. Analisis bivariat untuk mengetahui hubungan antara asupan protein dengan kadar protein ASI menggunakan uji bila data berdistribusi normal maka menggunakan uji Pearson, bila data berdistribusi tidak normal menggunakan uji korelasi Rank Spearman. Penelitian ini telah memperoleh persetujuan dari Komisi Etik Penelitian Kesehatan (KEPK) Fakultas Kedokteran Universitas Diponegoro/ Rumah Sakit Umum Pusat dr. Karyadi No.0154/EC/H/FK-UNDIP/V/2019.

\section{HASIL}

\section{Karakteristik Subjek}

Data karakteristik subjek penelitian berupa pendidikan, pekerjaan, rerata asupan energi dan protein disajikan pada tabel 1 . Tabel 1 diketahui bahwa sebagian besar asupan energi dan protein subjek kurang, yaitu sebanyak 93,94\% subjek yang asupan energinya kurang dan seluruh subjek asupan proteinnya kurang. Sebagian besar subjek bekerja sebagai buruh $(42,4 \%)$ dan ibu rumah tangga sebesar $30,3 \%$. Tingkat pendidikan rendah (SD dan SMP) sebanyak $51,5 \%$. Sebagian besar subjek memiliki status gizi overweight $(48,5 \%)$ dan normal $(36,4 \%)$.
Tabel 1. Karakteristik Subjek Penelitian

\begin{tabular}{lll}
\hline Variabel & n & \% \\
\hline Pendidikan & 10 & 30,3 \\
SD & 7 & 21,2 \\
SMP & 11 & 33,3 \\
SMA & 5 & 15,2 \\
Diploma & & \\
Pekerjaan & 10 & 30,3 \\
IRT & 14 & 42,4 \\
Buruh & 6 & 18,2 \\
Pedagang & 3 & 9,1 \\
Pegawai & & \\
Asupan energi & 31 & 93,9 \\
Kurang & 2 & 6,1 \\
Cukup & & \\
Asupan protein & 33 & 100 \\
Kurang & 0 & 0 \\
Cukup & & \\
Status Gizi & 1 & 3,0 \\
Kurus & 12 & 36,4 \\
Normal & 16 & 48,5 \\
Overweight & 4 & 12,1 \\
Obesitas & &
\end{tabular}

Dilihat dari Tabel 1 diketahui asupan responden tergolong kurang, hampir keseluruhan responden mengalami energi kurang yaitu 31 responden dari jumlah total 33 responden. Dapat dilihat asupan protein responden belum sesuai yang diharapkan, seluruh responden sebanyak 33 mengalami asupan protein kurang.

Data karakteristik subjek penelitian berupa rerata usia dan rerata kadar protein ASI disajikan pada tabel 2. Tabel 2 menunjukkan rerata usia subjek pada penelitian ini adalah 28,7 tahun yang termasuk kelompok dewasa awal. Rerata kadar protein ASI pada subjek penelitian sebesar 1,61\%. Rerata berat badan subjek 61,67 kg, tinggi badan 156,12 dan IMT $25,28 \mathrm{~kg} / \mathrm{m}^{2}$ tergolong overweight.

Tabel 2. Karakteristik Subjek Penelitian

\begin{tabular}{ll}
\hline Variabel & Rerata \pm SB \\
\hline Usia (th) & $28,7 \pm 4,95$ \\
Kadar protein ASI $(\%)$ & $1,61 \pm 0,46$ \\
BB $(\mathrm{kg})$ & $61,67 \pm 8,77$ \\
TB $(\mathrm{cm})$ & $156,12 \pm 4,55$ \\
IMT $\left(\mathrm{kg} / \mathrm{m}^{2}\right)$ & $25,28 \pm 3,29$ \\
\hline
\end{tabular}

Tabel 3. Rerata Asupan Protein dan Energi

\begin{tabular}{lccc}
\hline \multicolumn{1}{c}{ Variabel } & Nilai Tengah & Min - Mak & Rerata \pm SB \\
\hline Asupan energi (kkal) & 1939 & $1288-2492$ & $1882,7 \pm 303,65$ \\
Asupan protein (gr) & 58,20 & $35,2-77,6$ & $58,06 \pm 10,51$ \\
Kecukupan energi (\%) & 74,22 & $50,11-94,10$ & $72,95 \pm 11,90$ \\
Kecukupan protein (\%) & 47,70 & $29,40-69,58$ & $49,74 \pm 9,29$ \\
\hline
\end{tabular}


Tabel 3 menunjukkan rerata asupan protein sebesar 58,06 gram per hari dan rerata asupan energi sebesar 1882,7 kkal/hari. Rerata tingkat kecukupan asupan energi subjek sebesar 72,95\% dari 31 subjek 93,9\% dari 33 sampel yang tergolong kurang. Begitu pula dengan rerata tingkat kecukupan asupan protein subjek juga tergolong kurang yaitu hanya mencukupi sebesar $69,58 \%$ dari kebutuhan. $100 \%$ setara 33 subjek tergolong kurang.

\section{Hubungan Asupan Protein dan Energi dengan Kadar Protein ASI}

Gambar 1 dan 2. menunjukkan adanya hubungan signifikan antara asupan energi dan protein dengan kadar protein ASI $(\mathrm{p}<0,05)$ pada uji korelasi Rank Spearman. Asupan protein dengan kadar protein ASI memiliki kekuatan hubungan sedang ( $r=0,381)$, begitu pula asupan energi dengan kadar protein ASI juga memiliki kekuatan hubungan sedang $(r=0,40)$. Koefisien korelasi kedua variabel bernilai positif yang berarti semakin tinggi asupan energi dan protein maka semakin tinggi pula kadar protein ASI.

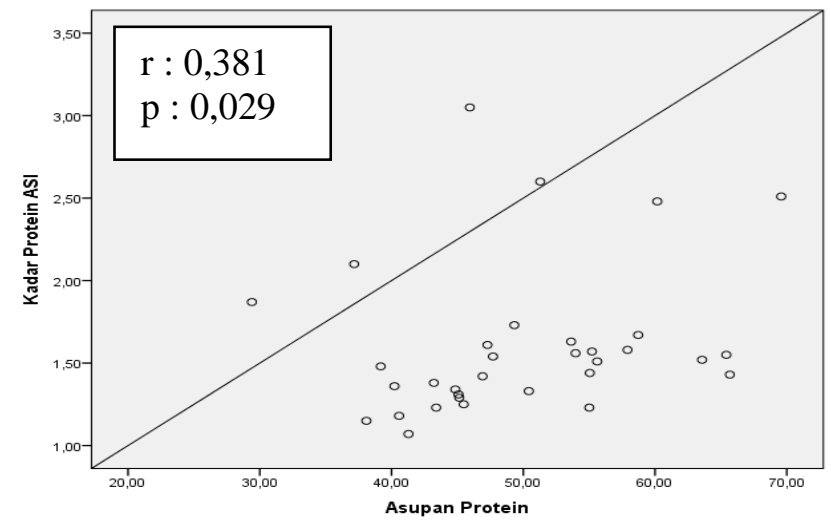

Gambar 1. Hubungan Asupan Protein dengan Kadar Protein ASI

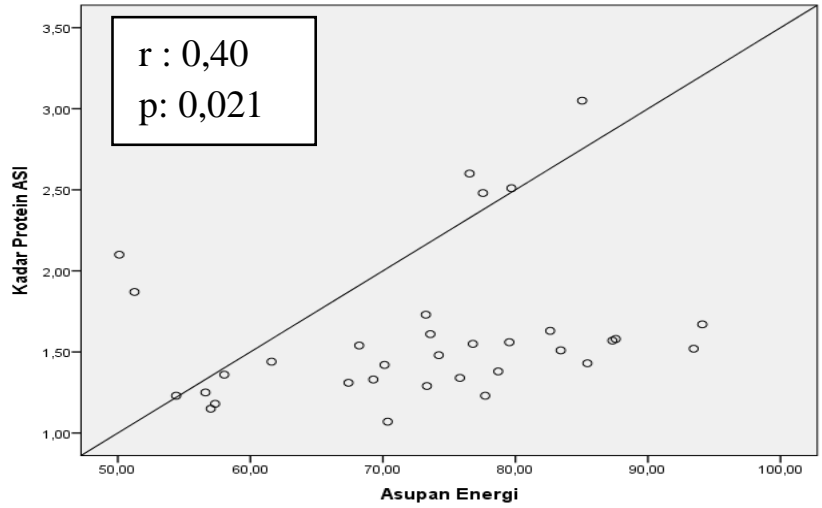

Gambar 2. Hubungan Asupan Energi dengan Kadar Protein ASI

\section{PEMBAHASAN}

Hasil uji statistik dengan uji korelasi Rank Spearman menunjukkan adanya hubungan signifikan antara asupan energi dan protein dengan kandungan protein pada ASI dengan nilai $\mathrm{p}<0,05$. Hasil penelitian ini berbeda dengan penelitian yang dilakukan oleh Adesty pada tahun 2016 yang menunjukkan tidak ada hubungan yang signifikan antara asupan dengan kandungan makro pada ASI. Perbedaan hasil penelitian tersebut dapat dikarenakan asupan makanan pada ibu menyusui tergolong kurang dan pengambilan sampel ASI dengan metode yang berbeda. Sebagian besar responden pada penelitian ini memiliki usia menyusui 5-6 bulan. Selain asupan, yang dapat mempengaruhi karakteristik serta kandungan zat gizi makro pada ASI adalah paritas, kembalinya masa menstruasi, dan frekuensi menyusui.

Hasil penelitian ini menunjukkan bahwa ada hubungan antara asupan protein dengan kandungan protein pada ASI ibu menyusui 6 bulan pertama $(\mathrm{p}<0,05)$. Asupan protein memiliki korelasi sedang dengan kandungan protein pada ASI $(r=0,381)$. Koefisien korelasi bernilai positif yang berarti semakin tinggi protein maka semakin tinggi pula kadar protein ASI. Asupan ibu menyusui dapat mempengaruhi komposisi ASI melalui beberapa cara jalur metabolisme yang menghasilkan efek tidak langsung. ${ }^{17}$ Namun, literatur menunjukkan bahwa beberapa jalur metabolisme memodulasi komponen ASI tertentu secara langsung melalui asupan makanan. ${ }^{18}$ Hasil penelitian ini sejalan dengan hasil penelitian di Swedia yang melaporkan bahwa kandungan total protein ASI lebih tinggi pada ibu yang mengkonsumsi diet tinggi protein $(8,83$ gram/hari) dibandingkan ibu dengan diet rendah protein $\left(7,31\right.$ gram/hari) $(\mathrm{p}<0,05) .{ }^{19}$

Metabolisme protein pada makanan yang tergolong protein nabati terlindung oleh dinding sel yang terdiri atas selulosa, yang tidak dapat dicerna oleh cairan pencernaan, sehingga daya cerna sumber protein nabati pada umunya lebih rendah dibandingkan dengan sumber protein hewani. Memasak makanan dengan memanaskannya akan merusak dan memecahkan dinding sel tersebut, sehingga protein yang terdapat di dalam sel menjadi terbuka dan dapat dicapai oleh cairan pencernaan saluran gastrointestinal. ${ }^{20}$

Pencernaan protein makanan didalam rongga mulut, protein makanan belum mnegalami proses pencernaan. Baru di dalam lambung terdapat enzim pepsine dan HCL yang bekerjasama memecah protein makanan menjadi metabolite intermediate tingkat polypeptide, yaitu peptone, aloumosa dan proteosa. Di dalam duodenum protein makanan yang sudah mengalami pencernaan parsial itu dicerna lebih lanjut oleh enzim yang berasal dari cairan pancreas dan dari dinding usus halus. Pancreas menghasilkan enzim-enzim proteolik trypsine dan 
chemotrypsine, sedangkan sekresi dinding usus mula-mula disangka hanya terdiri atas satu enzim yang diberi nama erepsine, tetapi kemudian ternyata erepsine tersebut merupakan campuran dari sejumlah enzim -enzim oligopeptidase, yaitu yang memecah ikatan-ikatan oligopeptida. Oleh erepsine, oligopeptida dipecah lebih lanjut menjadi asamasam amino. Cairan empedu tidak mengandung enzim yang memecah protein. ${ }^{21}$

Absorpsi dan transport di dalam usus halus protein makanan dicerna total menjadi asam-asam amino, yang kemudian di serap melalui sel- sel epithelium dinding usus. Semua asam amino larut di dalam air sehingga dapat berdifusi secara pasif melalui membrane sel. Ternyata kecepetan dan mudahnya asam amino menembus membrane sel melebihi hasil difusi pasif, dan untuk berbagi asam amino tidak sama, ada yang lebih mudah dan cepat, tetapi ada yang lebih lambat penyerapannya.

Pada gangguan pencernaan dan penyerapan, protein makanan dapat ke dalam colon dan dipecah oleh mikroflora usus. Pemecahan protein oleh microflora usus menimbulkan proses pembusukan. Dekarboksilasi asam-asam amino menghasilkan berbagai ikatan amino yang toksik. Zat -zat toksik ini dapat diserap oleh tubuh dan memeberikan keluhan-keluhan, seperti demam dan gatal-gatal. Atas dasar inilah terdapat orang-orang yang allergis terhadap beberapa jenis makanan sumber protein, terutama jenis ikan laut, kerang dan udang. Malah ada pula kasus allergic terhadap air susu.

Asam amino yang dibuat dalam hati, maupun yang dihasilkan dari proses katabolisme protein dalam hati, dibawa oleh darah kedalam jaringan untuk digunakan.proses anabolik maupun katabolik juga terjadi dalam jaringan diluar hati. Asam amino yang terdapat dalam darah berasal dari tiga sumber, yaitu absorbsi melalui dinding usus, hasil penguraian protein dalam sel dan hasil sintesis asam amino dalam sel. Banyaknya asam amino dalam darah tergantung keseimbangan antara pembentukan asam amino dan penggunaannya. Hati berfungsi sebagai pengatur konsentrasi asam amino dalam darah. ${ }^{22}$

Mekanisme produksi ASI secara fisiologis, terdapat beberapa jenis hormone yang berperan dalam mekanisme pembentukan ASI, diantaranya hormone progesterone berperan merangsang pembentukan lobus dan alveoli, hormone estrogen memicu pelebaran duktus di kelenjar mammae serta merangsang hipofisis anterior dalam mengeluarkan prolactin, dan human chorionic somatomammotropin(hCS) merupakan hormone plasenta yang berperan dalam sintesis enzim yang berguna untuk produksi ASI. ${ }^{23}$

Pada semester awal kehamilan, kelenjar mammae telah mampu memproduksi ASI. Akan tetapi, kinerja hormone prolactin dalam memproduksi ASI dihambat dengan tingginya kadar estrogen dan progesterone. Mekanisme tersebut masih berlanjut hingga sesaat sebelum plasenta dilahirkan. Pada saat plasenta dilahirkan, kadar hormon estrogen dan progesterone menurun drastic, menyebabkan hormone prolactin dapat bekerja untuk mensekresi ASI.

Setelah kelahiran, terdapat dua hormone lain yang bekerja untuk mempertahankan proses laktasi, yaitu hormone prolactin untuk meningkatkan sekresi ASI dan hormone oksitosin yang menyebabkan ejeksi ASI. Kedua hormone ini dirangsang oleh reflex neuroendokrin saat bayi menghisp putting ibu. Dalam jangka waktu 2-3 minggu, kadar serum prolactin pada ibu post-partum yang tidak menyusui akan kembali ke nilai normal seperti kondisi sebelum kehamilan, tetapi pada ibu menyusui kadar serum prolactin akan meningkat dengan adanya rangsangan dari putting susu. Saat bayi menghisap putting susu, terjadi rangsangan saraf sensorik di sekitar areola.

Impuls aferen dihantarkan ke hipotalamus, mengawali pelepasan oksitosin dari hipofisis posterior. Bersamaan dengan pembentukan prolaktin oleh adenohipofisis, rangsangan yang berasal dari isapan bayi ada yang dilanjutkan ke neurohipofisis (hipofisis posterior) yang kemudian dikeluarkan oksitosin. Melalui aliran darah, hormon ini diangkut menuju uterus yang dapat menimbulkan kontraksi pada uterus sehingga terjadi involusi dari organ tersebut. Oksitosin yang sampai pada alveoli akan mempengaruhi sel mioepitelium.

Kontraksi dari sel akan memeras air susu yang telah terbuat keluar dari alveoli dan masuk ke sistem duktulus yang untuk selanjutnya mengalir melalui dukus laktiferus masuk ke mulut bayi.Sesaat sebelum ASI keluar terjadi peningkatan hormone berdasarkan lion oksitosin, dan pelepasan hormone berlanjut setelah beberapa kali dilakukan penghisapan oleh bayi. Hormon oksitosin diproduksi oleh bagian belakang kelenjar hipofise. Hormon tersebut dihasilkan bila ujung saraf disekitar payudara dirangsang oleh isapan. ${ }^{24}$ Oksitosin dialirkan melalui darah menuju ke payudara yang akan merangsang kotraksi otot sekeliling alveoli (pabrik ASI) dan memeras ASI keluar dari pabrik ke gudang ASI. ${ }^{25}$ Pelepasan oksitosin dihambat oleh katekolamin. Pelepasan katekolamin dirangsang oleh factor stress dan nyeri. ${ }^{24}$

Hasil uji statistik dengan uji korelasi Rank Spearman menunjukkan adanya hubungan signifikan antara asupan energi dan protein dengan kandungan protein pada ASI dengan nilai $\mathrm{p}<0,05$. Hasil penelitian ini menunjukkan bahwa ada hubungan antara asupan energi dengan kandungan 
protein pada ASI ibu menyusui 6 bulan pertama $(\mathrm{p}<0,05)$. Asupan energi memiliki korelasi sedang dengan kandungan protein pada ASI $(r=0,40)$. Pola makan yang melancarkan produksi asi seperti adanya asupan makanan yang cukup di konsumsi ibu sehingga kebutuhan energi tubuh terpenuhi, energi yang dalam tubuh berubah menjadi hormon prolaktin. Keluarnya hormon prolactin menstimulasi sel di dalam alveoli untuk memproduksi ASI. ${ }^{26}$, hormon prolaktin berkaitan dengan nutrisi ibu, semakin asupan nutrisinya baik maka produksi yang dihasilkan juga banyak, untuk mengeluarkan asi diperlukan hormone oksitosin yang kerjanya dipengaruhi oleh proses isapan bayi semakin puting susu diisap.

Setiap 100 cc ASI berkemampuan memasok 67-77 kkal. Efesiensi konversi energi terkandung dalam makanan menjadi energy susu sebasar ratarata 80\%, dengan kisaran 76-94\%. Dapat diperkirakan besaran energy yang diperlukan untuk menghasilkan $100 \mathrm{cc}$ susu yaitu sekitar $85 \mathrm{kkal}$. Rata-rata produksi ASI sehari mencapai $850 \mathrm{cc}$ yang berarti mengandung 600kkal. Sementara itu kalori yang dihabiskan untuk menghasilkan ASI sebanyak itu adalah $750 \mathrm{kkal}$. Jika laktasi berlangsung lebih dari 3 bulan, dan selama itu berat badan ideal ibu menurun, berarti jumlah kalori tambahan harus ditingkatkan rofles dan S.ares 27,14

Asupan gizi adalah susunan makanan yang dikonsumsi setiap hari untuk memenuhi kebutuhan tubuh dalam satu hidangan. ${ }^{28}$ Pada waktu menyusui ibu harus makan-makanan yang cukup agar mampu mneghasilkan ASI yang cukup bagi bayinya., memulihkan kesehatan setelah melahirkan dan memenuhi kebutuhan nutrisi yang meningkat karena kegiatan sehari-hari yang bertambah. Ibu memerlukan zat gizi lebih banyak dari pada saat hamil. Banyaknya makanan ibu menyusui disesuaikan umur bayi dan kebutuhan gizi ibu. ${ }^{29}$

Asupan gizi yang kurang menyebabkan kebutuhan gizi yang diperlukan untuk memproduksi ASI diambil dari tubuh ibu. Jika keadaan ini dibiarkan berlarut-larut, maka selain kondisi tubuh ibu akan terganggu, produksi ASI pun akan berkurang, kalitasnya menurun, dan jangka waktu menyusui menjadi relative sinngkat. ${ }^{30}$ Asupan gizi yang dikonsumsi baik dan sesuai dengan seimbang diharapkan dapat membantu produksi ASI subjek dapat mencukupi kebutuhan bayinya.

Ibu menyusui 6 bulan pertama membutuhkan tambahan asupan energy sebesar $700 \mathrm{kkal} / \mathrm{hari}$ dan protein $20 \mathrm{~g} /$ hari. Kebutuhan gizi ibu menyusui dapat dipenuhi dengan meningkatkan serta menjaga kecukupan asupan. ${ }^{31}$ Kebutuhan asupan makanan ibu menyusui ikut bertambah berdasarkan anjuran kebutuhan asupan makanan yang dilihat dari usia ibu dengan usia menyusui. ${ }^{31,32}$ Pendidikan adalah usaha manusia untuk menumbuhkan dan mengembangkan potensi-potensi pembawa baik jasmani maupun rohani sesuai dengan nilai-nilai yang ada dalam masyarakat dan kebudayaan. ${ }^{33}$ Pendidikan merupakan salah satu factor penting untuk mendapatkan dan mencerna informasi secara lebih mudah. Akhirnya pemahaman suatu perubahan kondisi akan lebih mudah dipahami dan diinternalisasi. ${ }^{34}$

Dapat dikatakan factor-faktor pendidikan tidak mempengaruhi kualitas ASI khusunya kadar protein., factor internal ibu lebih banyak mempengaruhi. Pendidikan merupakan salah satu factor yang mempengaruhi pengetahuan, pendidikan yang telah ditempuh oleh seseorang maka akan mempengaruhi pengetahuan mereka tentang gizi. Pengetahuan gizi yang baik akan menyebabkan seseorang mampu menyusun menu yang baik untuk dikonsumsi. Semakin banyak pengetahuan gizi seseorang maka akan semakin memperhitungkan jenis dan jumlah makanan yang diperolehnya untuk dikonsumsi. ${ }^{35}$

Sebagian besar responden mempunyai asupan energy dan protein yang kurang dari rekomendasi yang dibutuhkan. Rerata asupan energi sebesar $72,95 \%$ dari kebutuhan dan rerata asupan protein sebesar 49,74\% dari kebutuhan. Kondisi ini dapat dikaitkan dengan sebagian besar pekerjaan subjek dan keluarga hanya sebagai buruh. Pendidikan terakhir tergolong rendah sehingga menyebabkan daya beli kebutuhan makanan terbatas dan kurang adanya pengetahuan tentang pemilihan makanan yang bervariasi untuk dikonsumsi sehari-hari. Pemilihan bahan makanan serta pola makan subjek yang kurang bervariasi dengan porsi yang sedikit dengan alasan tidak sempat untuk makan berdampak pada rendahnya energi serta protein pada ibu. ${ }^{36}$ Jenis makanan yang dikonsumsi relatif sama setiap harinya, subjek memilih memasak satu hari sekali untuk dikonsumsi pagi, siang dan malam. Jenis makanan yang dipilih berupa gorengan yang murah jika dibandingkan dengan harga makanan dengan sumber protein hewani. ${ }^{37}$

Berdasarkan rerata kadar protein ASI pada penelitian ini sebasar 1,61\%. Hasil pnelitian ini lebih tinggi bila dibandingkan dengan referensi yang ada. Dasar ketentuan ini ialah tiap $100 \mathrm{cc}$ ASI mengandung 1,2 g/100 ml protein. ${ }^{38}$ Dari referensi lain kandungan protein ASI kurang lebih 1,5 g/100 ml. ${ }^{39} \quad$ Belum ada standart baku yang direkomendasikan untuk melihat kadar protein ASI. Dengan demikian, $850 \mathrm{cc}$ ASI mengandung $10 \mathrm{~g}$ protein. Efisiensi konversi protein makanan menjadi protein susu hanya $70 \%$ (dengan variasi perorangan,tentu saja). Peningkatan kebutuhan ini 
ditujukan bukan hanya untuk transformasi menjadi protein susu, tetapi juga untuk sintesis hormone yang memproduksi (prolaktin)serta yang mengeluarkan ASI (oksitosin). Air susu yang keluar pada hari pertama sesudah melahirkan (kolostrum) mengandung $15 \%$ protein yang terdiri dari laktalbumin, laktaglobulin dan kasein, yang semuanya sangat bermanfaat untuk bayi. Jika ibu sehat, maka ibu dapat menyusui pada hari pertama melahirkan. Sebanyak $75 \%$ dari jumlah air susu ibu (ASI) didapatkan bayi selama lima menit pertama menyusui. ${ }^{38}$

\section{SIMPULAN}

Asupan protein dan energi berhubungan signifikan dengan kadar protein air susu ibu (ASI). Perlu diberikan edukasi pada ibu menyusui tentang pentingnya mengetahui kebutuhan asupan makanan yang sesuai rekomendasi agar kebutuhan tercukupi. Promosi kesehatan pada masyarakat khusunya ibu hamil dan menyusui untuk merubah perilaku dalam penggunakan pengganti air susu ibu serta makanan pendamping ASI sebelum umur 6 bulan. Hasil penelitian ini perlu dilakukan penelitian lebih lanjut dengan menganalisis faktor-faktor yang mempengaruhi kadar protein dan energi ASI atau kualitas ASI.

\section{DAFTAR PUSTAKA}

1. Kent, G. Chid feeding and human right. International Breastfeeding Journal. 2006;1:112. Avaliable from http://www.biomedcentral.com/content/pdf/174 6-4358-1-27. Diakses pada tanggal 31 Mei 2018,

2. Breastfeeding And The Mother-Child relationship : A Case Study Of Ebonyi State University Teaching Hospital, Abakaliki, African Journal Of Primary Healt Care And Family Medicine (serial online).2010:2:13.Avaliable

from http://www.phcfm.org/index.php/phcfm/article/ viewFile/97/63. Diunduh pad tanggal $31 \mathrm{Mei}$ 2018.

3. Riksani, R. Keajaiban ASI. Jakarta. Dunia Sehat; 2012.

4. Perinasia. Manajemen laktasi. Menuju persalinan aman dan bayi lahir sehat. Jakarta : $2^{\text {nd }}$-ed $; 2004$

5. Kodrat, Laksono. Dahsyatnya ASI \&Laktasi. Yogyakarta : Media Baca.2010

6. Inisiasi Menyusui dini [ebook].[Cited:2014Feb12] avaliable from : http://www.inisiasimenyusudini.com
7. Ikatan Dokter Anak Indonesia. Nutrisi Pediatrik dan Penyakit Metabolik Jilid I. Jakarta: Badan penerbid IDAI. 2011.

8. Kristiyanasari, W. ASI, menyusui \& sadari. Yogyakarta: Nuha Medika.2011

9. Bobak,dkk. Buku Ajar (Keperawatan Maternitas- edisi 4) Jakarta : EGC.2005

10. Mega M. Perbandingan Kadar Protein Dan Lemak Dalam ASI “X”, Susu Sapi Formula "Y" dan Susu Kedelai Formula "Z". Jurnal Ilmiah Mahasiswa Universitas Surabaya. 2013. Vol.2 No.2 (diakses pada maret 2018)

11. (G Gorkay, P Singhi, H U Okafar, A ElNawawy, K Elizabeth, B Jeffery, Samir K Saha, Mother and Child Nutrition in the Tropics and Subtropics: Chapter 5 Breast feeding.2015).

12. Kretchmer N, Zimmermen M. Development Nutrition.USA: Allyn and Bacon Vidcom Company; 1997; 171-241.

13. Koo Winston, Tank Surinder, Martin Sandra and Shi Runhua. Human Milk and Neurodevelopment in Children with Very Low Birth weight: a Systematic review. Nutrition Journal.2014; 13;94.

14. S. Ares Segura et al.The Importance of maternal nutrition during breastfeeding: Do breastfeeding mothers need nutritional supplements. Anales de pediateia. 2015

15. Profil kesehatan provinsi jawa tengah. Situasi derajat kesehatan 2017, dinas kesehatan kota semarang. Profil kesehatan semarang. Semarang 2017.

16. siti zulaikhah. Factor-faktor yang berhubungan dengan pemberian asi eksklusif di kecamatan sumowono kabupaten semarang(skripsi). Universitas Negeri Semarang : fakultas kesehatan masyarakat.2010

17. Novak EM, Innis SM. Impact of maternal dietary n-3 and n-6 fatty acids on milk mediumchain fatty acids and the implications for neonatal liver metabolism Am J Physiol Endocrinol Metab 2011;301:E807-17.

18. Dorea JG. Selenium and breast-feeding. $\mathrm{Br} \mathrm{J}$ Nutr 2002;88:443-61

19. Forsum E, Lonnerdal B. Effect of protein intake on protein and nitrogen composition of breast milk. Am J Clin Nutr 1980;33:1809-13 pada Francesca Bravi, Frank Wiens, Adriano Decarli, Alessia Dal Pont, Carlo Agostoni,and Monica Ferraroni. Impact of maternal nutrition on breast-milk composition: A systematic Review. Am J Clin Nutr 2016;104:646-62.

20. Almatsier, S, Prinsip Dasar Ilmu Gizi, Pt Gramedia, Jakarta,2006.

21. Campbel,Biologi, Erlangga,Jakarta,2002 
22. Mayes,peter A, Biokimia harper, Buku Kedokteran,Jakarta.1992

23. Sherwood L. Human physiology: From cells to systems. 8 th ed. USA: Thomson Brooks/Cole; 2013.

24. Anderson PO, Valdes V. A critical review of pharmaceutical galactagogues. Breastfeed Med. 2007;2(4):229-42.

25. I. Soetjiningsih, DSAK.ASI: Petunjuk Untuk Tenaga Kesehatan. Jakarta : EGC;1997

26. Jannah, N. 2012. Buku Ajar Asuhan Kebidanan: Kehamilan. Yogyakarta: Andi OF SET.

27. Rofles, S.R.,Pinna,K.\& Whitney,E. Understanding Normal and Clinical Nutrition. $8^{\text {th }}$ ed. USA: Wadsworth Cengange Learning.2009.

28. Almatsier, S. 2004. Prinsip Dasar Ilmu Gizi, PT. Gramedia Pustaka Umum :Jakarta.

29. Departemen Kesehatan R.I. 2002. Profil kesehatan Indonesia 2001 Menuju Indonesia sehat 2010, Departemen Kesehatan RI : Jakarta.

30. Ihsan, F. 2005. Dasar-dasar Kependidikan. PT Rineka Cipta : Jakarta.

31. Gibson,RS. Princples of Nutritional Assessment, Oxford University Press. New York. 1990. Di dalam : Gumala. Tingkat Konsumsi Zat Gizi Berdasarkan Karakteristik pasien di BPK RS Jiwa. Provinsi Bali.2011.
32. Haileslassie Kiday, Mulugeta and Meron Girma. Feeding practices, Nutritional status and associated factors o lactating women in Samre Woreda, South Eastern Zone ofTigray, Ethiopia. Nutritional Journal. 2013;12:28

33. Kasdu, D., 2001. Info Lengkap Kehamilan \& Persalinan (edisi 1). 3G Publisher :Jakarta.

34. Videbeck\& Sheila L. (2008). Buku Ajar Keperawatan Jiwa.EGC : Jakarta.

35. Sediaoetama, A.D. 2004. Ilmu Gizi Jilid 1. Dian Rakyat : Jakarta.

36. Indrawati,A.2012. Hubungan status Pekerjaan Ibu dengan Pemberian Air Susu Ibu(ASI) Eksklusif pada Bayi Saat Usia 0-6 Bulan di Bidan Praktik Mandiri Kota Semarang. Available at : jurnal.abdihusada.com.accessed on Juli 18,2019.

37. Kementrian Perdagangan Republik Indonesia. Sistem pemantauan Pasar Kebutuhan Pokok(SP2KP). Informasi Pasar(home page on internet).[update 2019 juli 20].available from https://ews.kemendag.go.id/

38. Arisman. 2003. Gizi Dalam Daur Kehidupan. Buku Kedokteran EGC: Jakarta

39. Almatsier,S.,Soetarjo,S., Soekaertim,M. 2011. Gizi Seimbang Dalam Daur Kehidupan.PT.Gramedia Pustaka utama : Jakarta 